ПОЛЯнИНА Алла Керимовна - кандидат социологических наук, доцент кафедры менеджмента и государственного управления Национального исследовательского Нижегородского государственного университета им. Н.И. Лобачевского (603022, Россия, г. Нижний Новгород, пр-кт Гагарина, 23; Alker@yandex.ru)

ГРУДЗИНСКИЙ Александр Олегович - доктор социологических наук, профессор Национального исследовательского Нижегородского государственного университета им. Н.И. Лобачевского (603022, Россия, г. Нижний Новгород, пр-кт Гагарина, 23)

\title{
АНАЛИЗ ПРАКТИКИ ГОСУДАРСТВЕННОГО И ОБЩЕСТВЕННОГО КОНТРОЛЯ РЕКЛАМЫ И ПОДХОДОВ К ВЫЯВЛЕНИЮ НЕПРИСТОЙНОГО В РЕКЛАМНОЙ ПРОДУКЦИИ
}

\begin{abstract}
Аннотация. В статье исследуются практика социального контроля над рекламой, реализуемого экспертными советами всех 84 территориальных управлений ФАС России. Изучение опыта работы экспертных советов и организации опросов населения региональными управлениями ФАС выявляет основные характеристики социального контроля над неэтичной рекламой. Обобщение и анализ протоколов заседаний экспертных советов и других материалов о работе советов позволил выявить основные аргументы, используемые членами экспертных советов для оценки рекламы, на основании которых сформулированы общие критерии непристойной рекламы. Авторы выявляют повышение градуса эпатирования аудитории рекламы за счет превышения порога пристойности.
\end{abstract}

Ключевые слова: реклама, информационная безопасность детей, социальный контроль, непристойность, медиа, экспертный совет по рекламе, антимонопольная служба

\section{Постановка проблемы}

Социальная реальность наших дней уже не мыслится в отрыве от важнейшего фактора социальной динамики - многослойной самогенерирующейся медиарельности.

Если признать медиа, включая рекламу, «бесконечно саморазвивающейся средой, состоящей из многочисленных средств и каналов коммуникации в вербальной и невербальной форме» [Жилавская 2018], средой, приобретающей за счет визуализации «все более высокую температуру, освобождающую человека от трудности расшифровки» кода, можно определить тенденцию возрастания вредного воздействия рекламной информации на детей. Особая опасность, в частности, видится в таком свойстве медиа и рекламы, как виативность - способность пронизывать все элементы окружающего мира и способствовать диффузии контента в медиапространстве: растворившись в основном контенте, реклама кодирует культуру. Для привлечения внимания потребителя реклама должна будет стать еще более «горячей» лексически и по форме, задействовать насколько возможно все органы восприятия. Чтобы высветиться среди другого плотного информационного пространства, она должна быть гораздо «горячее», чем основной контент, в который она встраивается. В итоге реклама вынуждена будет стать шокирующей, наиболее «горячей», или исчезнуть вовсе, раствориться в медиа. Это и являет собою, на наш взгляд, основную тенденцию трансформации воздействия рекламы на человека.

Недостаточность социального контроля над рекламой влечет производство культурных кодов исключительно в коммерческих интересах. Проблема социального контроля над оборотом информации, способной причинить вред здо- 
ровью и развитию детей, возникает на пересечении потребности общества в обеспечении безопасности детской группы и интересов хозяйствующих субъектов, бизнес-структур в области извлечения прибыли. В целях организации общественного контроля за применением законодательства о рекламе при региональных подразделениях Федеральной антимонопольной службы может быть образован консультативно-совещательный орган - Экспертный совет по применению законодательства о рекламе.

Федеральный закон «О защите детей от информации, причиняющей вред их здоровью и развитию» от 29.12.2010 № 436-Ф3 содержит расширенное по сравнению с федеральным законом № 38-Ф3 от 13.03.2006 «О рекламе» понимание информационных рисков для детей, в частности отнесение изображения или описания половых отношений между мужчиной и женщиной, а также бранных слов и выражений, не относящихся к нецензурной брани, к информации, ограниченной для распространения среди детей определенных возрастных групп. Однако Ф3 № 436, более поздний по сравнению Ф3 № 38, Ф3 № 436 не распространяется на регулирование отношений в сфере рекламы, и потому предусмотренный им механизм регулирования исключает рекламу из возрастной классификации в соответствии с критериями вредной информации. Ограничение распространения рекламной информации на основании таких критериев, как половые отношения, бранные слова и выражения, не относящиеся к нецензурной брани (указание на которые вовсе отсутствуют в Ф3 № 38, но имеют место в Ф3 № 436, может быть осуществлено в соответствии с положением Ф3 № 38, запрещающим непристойные образы, сравнения и выражения в рекламе (ст. 5, п. 6).

\section{Исследование практики социального контроля непристойной рекламы}

О.О. Савельева связывает скрытые последствия рекламного воздействия в форме «ментальной базы социального конфликта» с «масштабным несовпадением целевых и нецелевых аудиторий рекламы» при том, что нецелевая аудитория (реципиенты, не относящиеся к потребителям рекламы), «не рефлексируется рекламистом и не принимается им в расчет» при создании и размещении рекламы [Савельева 2006]. В контексте информационной безопасности детства именно дети являются нецелевой аудиторией. Проблемы неурегулированности рекламной сферы непосредственно связываются с выработкой единообразных критериев непристойности публичной информации и исследуются в основном в двух направлениях: как лингвистическое осмысление - лингвоэкология (лингвистическая экспертиза) [Брусенская, Куликова, Украинцева 2017] и правовое осмысление - обобщение судебной и правоприменительной практики [Копнина 2015]. Отсутствуют исследования существующей практики оценки этичности рекламы, которые бы позволили выявить, классифицировать и привести к единообразию используемые при этом критерии. Нами проведено исследование опыта анализа рекламы антимонопольным органом и действующими при территориальных управлениях экспертными советами.

Эмпирическую базу исследования составили информационные материалы, представленные на официальных сайтах территориальных органов ФАС, данные о проведенных УФАС опросах общественного мнения и протоколы заседаний экспертных советов с 2013 по 2018 г. В исследовании использован метод контент-анализа. Исследование охватило все 84 территориальных подразделе- 
ния Федеральной антимонопольной службы, осуществляющие деятельность в регионах России ${ }^{1}$.

Среди концептуальных категорий решающее знание имеет размещение непристойной рекламы в условиях городской среды (220 упоминаний), за ней следует единое языковое пространство (188 упоминаний), на 3-м месте находится эксплуатация сексуального инстинкта (95 упоминаний), замыкают ряд традиционные ценности (52 упоминания). Также в большинстве случаев (253 упоминания) оценке подлежал визуальный образ (изображение) (см. табл. 1). Выделены два вида неэтичной рекламы, требующей общественного контроля в связи с отсутствием точных правовых формулировок: 1) реклама, содержащая непристойные образы и выражения; 2) реклама, содержащая бранные слова и выражения (не относящиеся к нецензурной брани), завуалированную нецензурную брань или иную обсценную лексику.

Непристойные образы и непристойные выражения. Внимание членов экспертных советов привлекли такие примеры наружной рекламы, которые чаще всего связаны с образом обнаженного тела при рекламировании нижнего белья, спасалонов, ночных клубов и даже услуг и товаров, на первый взгляд не связанных с образом. Выделяются случаи наружной рекламы, признанной экспертным советом непристойной, но не только в связи с наготой и этикой половых отношений, а в связи с наличием (с целью эпатирования аудитории) атрибутов преступного или иного девиантного поведения, которое может спровоцировать несовершеннолетних на ведение соответствующего образа жизни. Например, реклама с изображением полуобнаженной девушки, которая с пистолетом в руках лежит на деньгах, была признана Экспертным советом при УФАС по Амурской обл. непристойной, т.к. содержит атрибуты корыстного преступления, насильственного преступления и преступления сексуального характера.

Часто впечатление о рекламе как о непристойной информации возникает в связи с сочетанием образа и выражения, которые могут по смыслу не соотноситься с рекламируемым товаром, сочетать несочетаемое: возвышенное в общественном сознании с «низким», порочным (например, образ школьницы в рекламе мужского клуба), что, по мнению членов экспертных советов, «оказывает особое негативное воздействие на детей и подростков, обесценивает образование и культуру» (УФАС Кировской обл.). «Знаки, бессознательно считываемые как символ», применяются также и как способ дискредитации конкурентов, например, признанная экспертным советом при УФАС по Красноярскому краю непристойной наружная реклама бара с изображением девушки с бананом во рту и подписью: «Теперь конкуренты знают, как себя занять».

При обсуждении негативного влияния изображений в рекламе на детей экспертные советы затронули опасность появления в рекламе так называемых мемов - графического образа с устоявшимся значением, служащего для схематического упрощения смысла явления, события, человека, однозначно интерпретируемых большинством интернет-пользователей. Опасность использования в рекламе мема заключается в трудности доказывания его значения,

1 Генеральной совокупностью, совпадающей с выборочной, являются протоколы экспертных советов, содержащие оценку рекламы на пристойность. Всего исследован 41 протокол, каждый из которых включает анализ от 2 до 4 образцов рекламной продукции (всего 123 образца). Единицей текста выступает формулировка аргумента члена совета в пользу признания рекламы непристойной. Концептуальной категорией как смысловой совокупностью принятых единиц текста являются: «традиционные ценности», «городская среда», «языковое пространство», «эксплуатация сексуального инстинкта». Данные единицы текста представляют собой сформулированные нами совокупности критериев, объединенных общим смыслом. Единицы текста также сопоставлены с принятым в исследовании делением непристойной рекламы на 3 вида: непристойные образы, непристойные выражения, нецензурные (бранные) слова. 
поскольку раскодирование мема доступно лишь для части аудитории, активно включенной в интернет-коммуникации.

Реклама, содержащая признаки непристойности в форме выражения, высказывания, слогана, требует отдельного рассмотрения. В данном случае непристойность выражения имеет отношение к его неприличному смыслу, узнаваемому человеком благодаря относимости к единому языковому пространству. Среди примеров можно выделить следующие: рекламы фитнес-клуба на транспортном средстве со слоганами: «Хочу тебя пригласить в фитнес-клуб», «Кончай бездельничать - иди на тренировку», «Давай займемся фитнесом» (УФАС по Омской обл.); реклама автомойки со слоганом «На@рала птичка на капот? Все быстро вымоет “Пилот”!» (УФАС по Архангельской обл.); реклама новостроек с изображением девушки и текстом: «Сосну каждому покупателю» (УФАС Карелия); реклама телефонов с текстом: «...У тебя большой... А она хочет mini?» (УФАС по Челябинской обл.); реклама автомойки с текстом: «Будет блестеть как у кота», реклама автомобильных шин со слоганом: «Когда шинам писец» и реклама шашлычной со слоганом: «Попробуй маминых люлей» (УФАС по Кировской обл.); реклама медицинского центра с образом мужчин и слоганом: «Перцем не стареть» (Мордовское УФАС); реклама сети фитнес-центров под лозунгом «SE [XS] будет! За 4900 рублей» (УФАС по Волгоградской обл.); реклама ресторана с текстом: «Секс и голод правят миром» (УФАС по Московской обл.).

Завуалированная обсиенная лексика и жаргонизмы. Для создания шокирующего эпатирующего эффекта, автоматически фокусирующего внимание населения, применяется так называемая эмотивная лексика, часто ассоциирующаяся с нецензурной лексикой. Это окказионализмы, созданные путем нарушения языковых законов и имеющие, как правило, грубо-просторечный характер, либо сами жаргонные выражения. Можно привести следующие примеры: реклама сервисного центра «Раз*Бал AUTO; Приезжай к нам!», размещенная на транспортном средстве (Московское УФАС); реклама мобильных телефонов, в которой цены названы «ОРЕХуительными» (УФАС по Челябинской обл.); реклама роллов: «Японуться - теперь можно» (УФАС по Пензенской обл.); реклама в торговом комплексе: «Цены просто ох...ть (охренеть)» (УФАС по Республике Чувашия); реклама на радио магазина электроинструментов, в которой пропевалась фраза «ах, уе..., ах, уе..., ах, уехала цена» (УФАС по Саратовской обл.); реклама лакокрасочных изделий, садовых и хозяйственных товаров содержит слоган: «Лаки, краски и клея - их на базе до...!» (УФАС по Ростовской обл.) и др.

Другим механизмом общественного контроля неэтичной рекламы является опрос общественного мнения, размещаемый на официальных сайтах УФАС или страницах в известных социальных сетях. Число участников опросов составляет от нескольких десятков до нескольких тысяч человек в зависимости от доступности информации о проводимых опросах, а также от активной организационной работы инициаторов оценки рекламы на пристойность (уровень организованности гражданской активности) и деятельности самих рекламистов по вовлечению в участие в опросах аффилированных лиц (сотрудников, клиентов, партнеров) с целью предотвращения юридической ответственности за ненадлежащую рекламу. Так, например, $78 \%$ участников опроса (163 голоса) ответили утвердительно на вопрос о содержании непристойных образов в наружной рекламе магазина интимных товаров в виде уличной надувной конструкции в форме женских ног, между которыми располагается вход в магазин (УФАС по Калининградской обл.). 47\% респондентов (6 404 голоса) признали использованные в рекламе ночного клуба образы непристойными в сочетании с выражениями: «А можно всех посмотреть?», «Люблю сверху», «Никогда не отказываю» и «Войди в меня». Реклама бургеров со слоганом: «Это лучшее, что 
было у меня во рту за 100 р.» с изображением девушки признали непристойной 56\% опрошенных (4 640 голосов) (УФАС по Алтайскому краю). Рекламу такси со слоганом: «О(-):- ЕННОЕ ТАКСИ» признали содержащей нецензурную лексику 53\% опрошенных из 311 граждан, участвовавших в опросе. Эту же рекламу оценил Экспертный совет при УФАС Мурманской области и признал непристойной, поскольку, как отмечает один из экспертов В.П. Лихошва, для восприятия человека привычнее видеть слово целиком (апперцептивность восприятия), и это заставляет подбирать подходящие слова (процесс заполнения), т.к. «троеточием обозначаются обычно места пропуска букв (чаще всего в бранных словах)».

\section{Выводы}

Таким образом, можно выделить основные критерии непристойной рекламы (факторы социального контроля рекламы), применяемые экспертными советами при УФАС:

1) публичность демонстрации рекламы в условиях городской среды, доступность для восприятия детьми;

2) изображение или описание интимных мест тела или интимного физиологического акта;

3) особенности (строгость) этических норм в конкретном регионе страны;

4) особенность восприятия детьми публичной информации как нормы поведения или модели для подражания;

5) ценность традиционных установок в отношении гендерных ролей и семьи;

6) принуждающий характер рекламного сообщения в замкнутом пространстве (лифт, транспорт);

7) близость к детским учреждениям, учреждениям культуры и науки, культовым строениям;

8) популяризация заниженных культурных стандартов;

9) скрытое воздействие на бессознательное при использовании символов и знаков;

10) эксплуатация половых инстинктов;

11) использование криминальной атрибутики;

12) использование слов и выражений, узнаваемых как бранные, обсценные, просторечные или нецензурные в условиях единого языкового пространства населения;

13) использование сочетания образа и текста, которое создает ассоциации с непристойным поведением, метафорическую эротическую трактовку;

14) созданные путем нарушения языковых законов окказионализмы, в т.ч. с помощью пропуска букв или последовательного сочетания слов, с целью прочтения нецензурного, жаргонного или грубо-просторечного слова;

15) использование букв иностранного алфавита для написания непристойного слова, выражения и мемов.

Дополнительными критериями выступают: плотность людского потока в месте размещения рекламы; указание в рекламе на информационную продукцию, ограниченную в распространении среди определенных возрастных категорий; выделение отдельных слов как специальный прием привлечения внимания.

Обобщение опыта работы экспертных советов способствует пониманию текущего состояния информационной среды развития ребенка, возможности для государства в лице специализированного органа оказывать управленческое воздействие на формирование безопасной городской среды, предотвращать и пресекать опасности, возникающие на пересечении экономической свободы и ценности здоровья и развития детей, а также демонстрирует степень активно- 
сти гражданского общества и характер взаимодействия власти и личной гражданской инициативы в условиях декларируемой демократии. Эффективность социального контроля над оборотом информации, способной причинить вред детям, означает действенность механизмов сдерживания «маркетизации» жизненного пространства, ограничения ресурсных возможностей рекламы по кодированию культуры в коммерческих целях, удержания от заражения рекламой всей медиасреды как контекста социальной ситуации развития ребенка и в целом являет собою необходимое условие организации информационной безопасности детства.

\title{
Список литературы
}

Брусенская Л.А. Куликова Э.Г. Украинцева И.В. 2017. Медиатизация: реклама как современный речевой жанр медиадискурса в контексте идей экологической лингвистики. - Медиаобразование. № 3. С. 61-78.

Копнина Г.А. 2015. Лингвистическая экспертиза спорных рекламных текстов: российская практика. - Экология языка и коммуникативная практика. № 2. C. 121-142.

Жилавская И.В. 2018. Теория всеоших медиа: опыт обоснования. - Медиа. Информация. Коммуникация: международный электронный научно-образовательный журнал. № 24. Доступ: http://mic.org.ru/new/676-teoriya-vseobshchikhmedia-opyt-obosnovaniya (проверено 22.01.2019).

Савельева О.О. 2006. Социология рекламного воздействия. М.: РИП-холдинг. $284 \mathrm{c}$.

POLYANINA Alla Kerimovna, Cand.Sci. (Soc.), Associate Professor of the Lobachevsky National Research State University of Nizhny Novgorod (bld. 1, 23 Gagarina Ave, Nizhny Novgorod, Russia, 603022; Alker@yandex.ru)

GRUDZINSKY Aleksandr Olegovich, Dr.Sci. (Soc.), Professor of the Lobachevsky National Research State University of Nizhny Novgorod (bld. 1, 23 Gagarina Ave, Nizhny Novgorod, Russia, 603022)

\section{AN ANALYSIS OF THE PRACTICE OF STATE AND PUBLIC CONTROL ON ADVERTISING AND APPROACHES TO THE DETECTION OF OBSCENE IN ADVERTISING PRODUCTS}

\begin{abstract}
The article investigates the mechanism of evaluation of obscene advertising by all 84 territorial administrations of the Federal Antimonopoly Service of Russia (FAS). The study of the experience of the Expert Councils at the regional offices of the FAS and the experience of organizing surveys reveals the main characteristics of social control over advertising products, ambiguous from the point of view of public perception of decency, and the problems of combining state and public control.

On the base of generalization of practices of Expert Councils and arguments of members of councils in the study of controversial advertising, the authors formulate common criteria of obscene advertising. They define the range of problems associated with the lack of regulation of the advertising business, the evaluation of advertising as a danger factor that has a powerful impact on the development of children. Analysis of the practice of evaluation of obscene advertising is approved as a necessary step to improve the system of information security of children. The study reveals the ability of the state, represented by a special authority, to manage the safety of the urban environment, to prevent and suppress the dangers arising at the intersection of economic freedom and the development of children.

Keywords: advertising, information security of children, obscenity, media, Expert Council on Advertising, antitrust service
\end{abstract}

